OPEN ACCESS

Edited by:

Lee Baumgartner,

Charles Sturt University, Australia

Reviewed by:

Anton J. Schleiss,

École Polytechnique Fédérale de Lausanne, Switzerland Marcos Callisto Federal University of Minas Gerais,

Brazil

*Correspondence:

Rafael M. Almeida

rafaelmalmeida2@gmail.com;

rafaelmarquesjf@yahoo.com.br

Fabio Roland

Fabio.roland@ufjf.edu.br

Specialty section

This article was submitted to

Freshwater Science,

a section of the journal

Frontiers in Environmental Science

Received: 30 March 2020

Accepted: 03 July 2020

Published: 22 July 2020

Citation:

Almeida RM, Hamilton SK

Rosi EJ, Barros N, Doria CRC,

Flecker AS, Fleischmann AS, Reisinger AJ and Roland F (2020) Hydropeaking Operations of Two

Run-of-River Mega-Dams Alter Downstream Hydrology of the Largest Amazon Tributary.

Front. Environ. Sci. 8:120. doi: 10.3389/fenvs.2020.00120

\section{Hydropeaking Operations of Two Run-of-River Mega-Dams Alter Downstream Hydrology of the Largest Amazon Tributary}

Rafael M. Almeida ${ }^{1,2,3 *}$, Stephen K. Hamilton ${ }^{2,4,5}$, Emma J. Rosi ${ }^{2}$, Nathan Barros ${ }^{1}$, Carolina R. C. Doria ${ }^{6}$, Alexander S. Flecker ${ }^{3}$, Ayan S. Fleischmann ${ }^{7}$, Alexander J. Reisinger ${ }^{8}$ and Fábio Roland ${ }^{1 *}$

${ }^{1}$ Department of Biology, Federal University of Juiz de Fora, Juiz de Fora, Brazil, ${ }^{2}$ Cary Institute of Ecosystem Studies, Millbrook, NY, United States, ${ }^{3}$ Department of Ecology and Evolutionary Biology, Cornell University, Ithaca, NY, United States, ${ }^{4}$ W. K. Kellogg Biological Station, Michigan State University, Hickory Corners, MI, United States, ${ }^{5}$ Department of Integrative Biology, Michigan State University, Hickory Corners, MI, United States, ${ }^{6}$ Department of Biology, Federal University of Rondônia, Porto Velho, Brazil, ${ }^{7}$ Institute of Hydraulic Research, Federal University of Rio Grande do Sul, Porto Alegre, Brazil, ${ }^{8}$ Department of Soil and Water Sciences, University of Florida, Gainesville, FL, United States

Large storage dams have widely documented impacts on downstream aquatic environments, but hydroelectric dams with little or no capacity for storage of water inflows (i.e., run-of-river) have received less attention. Two of the world's largest runof-river hydropower dams (Jirau and Santo Antônio, Brazil) are located on the Madeira River, the largest tributary to the Amazon River. Here we examine whether the Madeira dams have affected downstream seasonal flood pulses and short-term (daily and subdaily) flow dynamics. We show that the combined effects of these dams on seasonal flood pulses were modest. However, dam operations significantly increased day-today and sub-daily flow variability. The increase in short-term flow variability is largely explained by rapid, short-term variations in river flow caused by fluctuations in energy demand (hydropeaking). Both the magnitude of hydropeaking and the mean absolute day-to-day change in discharge downstream of the dams doubled after dam closure. In addition, the median hourly rate of water level change downstream of the dams was three times higher than upstream. Our findings highlight that even run-of-river dams on very large rivers such as the Madeira-whose average discharge at the dam site is larger than that of the Mississippi River at its mouth-can alter downstream hydrology through hydropeaking. Although little studied in tropical floodplain rivers, hydropeaking by large run-of-river dams may be detrimental to downstream aquatic organisms and human populations that utilize the river for navigation and fisheries.

Keywords: Madeira River, Amazon, hydroelectricity, sub-daily discharges, environmental flow, run-of-the-river, hydrology, flood pulse 


\section{INTRODUCTION}

Dams affect downstream ecosystems and their biodiversity through alteration of the frequency, magnitude, duration, timing, and rate of change of natural flow regimes (Richter et al., 1996; Poff et al., 1997; Nilsson and Berggren, 2000). Most of the existing knowledge on the downstream impacts of dams comes from storage dams with relatively large reservoirs, high flow regulation, and long water residence times, which cause significant disruption of downstream flow regimes (Lehner et al., 2011). Conversely, run-of-river hydroelectric facilities (i.e., hydroelectric generation with little or no active storage of water inflows) are generally thought to have lesser impacts on downstream hydrology (Csiki and Rhoads, 2014). However, runof-river dams can cause short-term fluctuations in downstream flow as a result of daily and sub-daily variation in flow releases to meet short-term variation in demand for electricity (Ashraf et al., 2018; Greimel et al., 2018), a phenomenon commonly known as hydropeaking. Most studies on the downstream impacts of run-of-river dams have examined relatively small dams located in North America and Europe (Anderson et al., 2015; Bejarano et al., 2018). It is not known how modern, large run-ofriver dams such as those newly constructed, under construction, and planned for the Amazon basin (Anderson et al., 2018; Almeida et al., 2019b) may affect downstream flow regimes. Understanding the hydrological effects of contemporary Amazon dam operations is especially important considering that past dam construction has caused substantial hydrological alterations in some Amazonian rivers (Timpe and Kaplan, 2017).

In unregulated large rivers, the natural flow regime is key to maintaining river and floodplain biodiversity, productivity, and ecosystem processes, supporting people through fisheries, harvest of other wild foods and products, and agriculture (Junk et al., 1989; Poff et al., 1997; McClain and Naiman, 2008; Lima et al., 2017). In recent years, new large dams have been proposed in many important tributaries of the Amazon River Basin (Winemiller et al., 2016; Anderson et al., 2018; Almeida et al., 2019b), raising concerns about downstream disruption of natural flows (Forsberg et al., 2017). One of the large Amazonian rivers with vast untapped hydroelectric potential is the Madeira
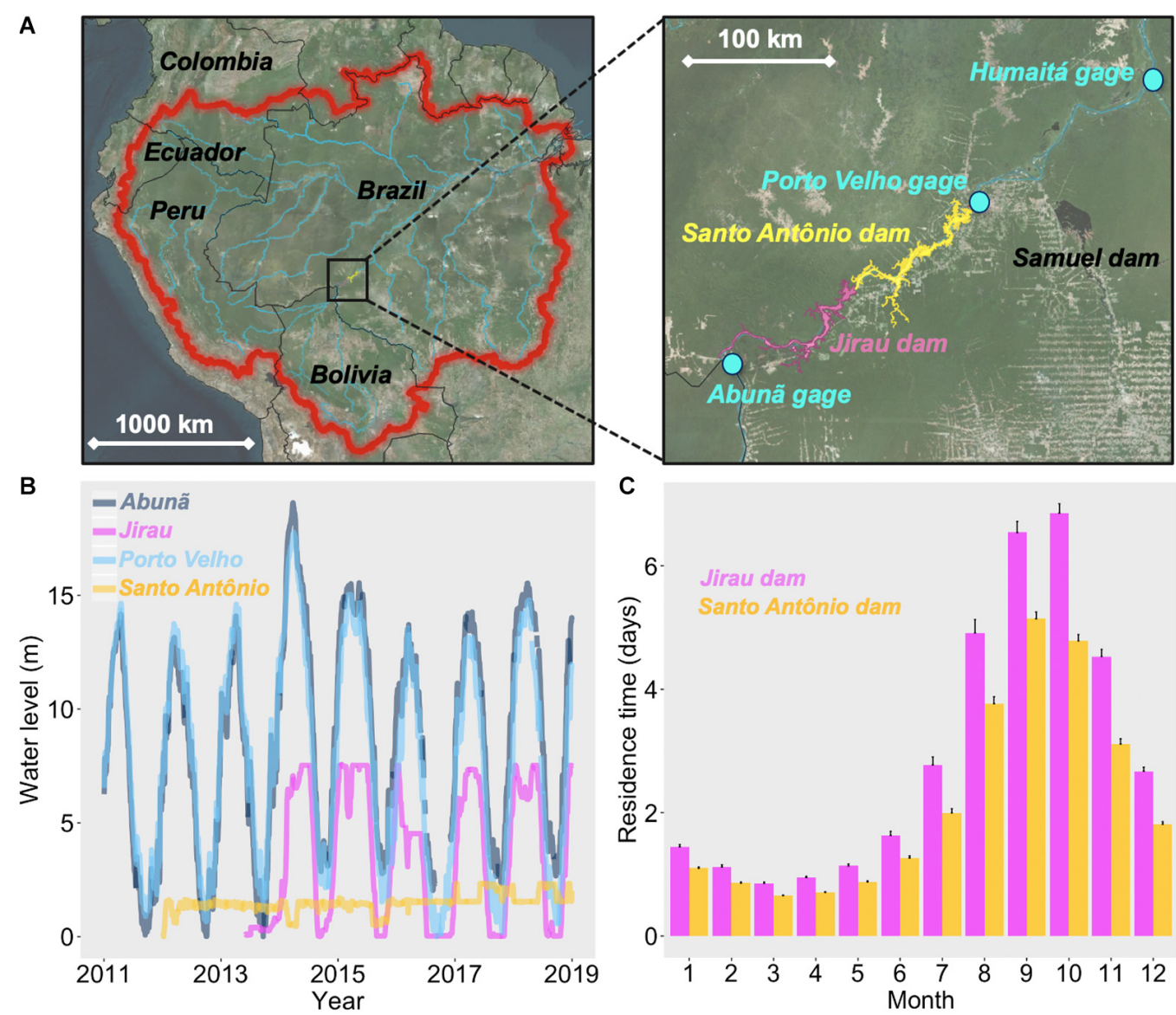

C

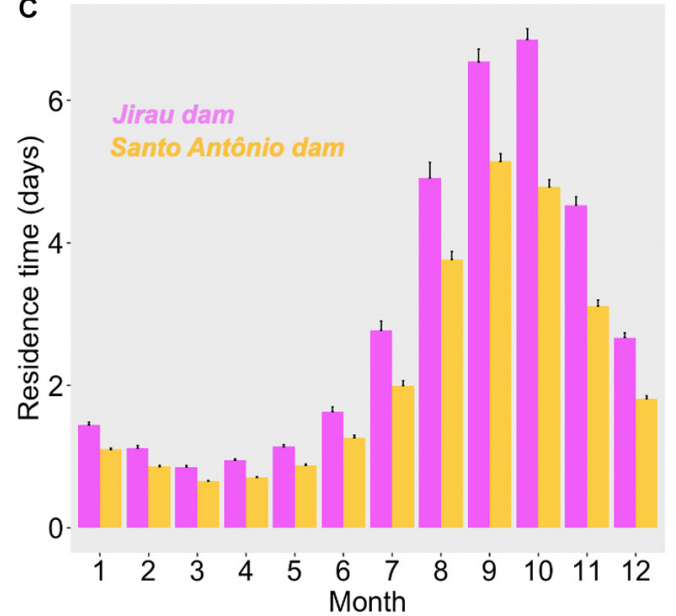

FIGURE 1 | Study site characterization. (A) Location of Jirau and Santo Antônio dams and the Abunã (upstream), Porto Velho (5 km downstream of Santo Antônio dam), and Humaitá (250 km downstream) gaging stations; the red outline indicates the Amazon basin limits. (B) Water level variation at Jirau dam, Santo Antônio dam, Abunã (upstream of both dams), and Porto Velho (downstream of both dams); data for Jirau and Santo Antônio are shown after the reservoirs were filled to full pool. Operational rules at Jirau are more variable to avoid inundation of Bolivian territory during low flows. (C) monthly average ( \pm standard error) of theoretical water residence times within both reservoirs between 2012 and 2018. The annual average residence time is 3.0 days at Jirau and 2.2 days at Santo Antônio. 
River, the largest source of water, sediments, and nutrients to the Amazon River mainstem (McClain and Naiman, 2008; Almeida et al., 2015).

Two of the world's largest run-of-river dams were built on the mainstem of the Madeira River in Brazil this decade (Jirau and Santo Antônio). As of 2020, several more dams have been proposed for upstream reaches (Almeida et al., 2019b), including large storage dams on tributaries (Forsberg et al., 2017). An analysis using environmental vulnerability indices has identified the Madeira as the Amazonian river system that is most threatened by dam construction (Latrubesse et al., 2017). Recent studies on the impacts of the Jirau and Santo Antônio dams report decreases in downstream fishery yields (Santos et al., 2018; Lima et al., 2020) and suspended sediment concentrations (Latrubesse et al., 2017) - although the attribution of suspended sediment changes to the dams has been questioned because concentrations have also decreased upstream of both reservoirs (Ayes et al., 2019). A remote sensing analysis has revealed that the area inundated by the Jirau and Santo Antônio dams is $60 \%$ larger than initially predicted in pre-dam environmental impact assessments (Cochrane et al., 2017), which may be in part related to changes in project design. Although the residence time of the Madeira dams is short (Figure 1), drowned tributary valleys created by the dams show significant limnological alterations, including thermal stratification and increased availability of organic matter (De Faria et al., 2015; Almeida et al., 2019a).

Understanding the environmental effects of the Madeira dams is critical to better document impacts, guide mitigation measures, and inform decisions on the siting and design of future Amazonian hydropower facilities. Here we use pre- and post-dam flow data from above and below the Madeira dams to examine whether they have affected downstream seasonal flood pulses and short-term flow dynamics. We hypothesized that minimal changes to seasonal flood pulses would be observed given the run-of-river design of the dams. In contrast, we expected that examination of sub-daily and day-to-day changes in discharge would reveal the existence and magnitude of hydropeaking.

\section{MATERIALS AND METHODS}

\section{Study Site}

With an area of 1.4 million $\mathrm{km}^{2}$, the Madeira River basin extends through Brazil, Peru, and Bolivia, covering 25\% of the Amazon basin. The Madeira River flows into the Amazon River downstream of Manaus, Brazil. The Jirau and Santo Antônio dams are two run-of-river dams built in the municipality of Porto Velho, about 1,000 km upstream of the Madeira River mouth (Figure 1). These dams are $\sim 100 \mathrm{~km}$ apart and were designed so that water inflows approximately equal outflows (i.e., run-ofriver), but damming has created reservoirs that are operated at a relatively constant water level throughout the year-particularly at Santo Antônio dam (Figure 1C). The downstream dam is Santo Antônio (installed capacity: 3,568 MW, reservoir area: $471 \mathrm{~km}^{2}$, total reservoir volume: $2075 \times 10^{6} \mathrm{~m}^{3}$, reservoir length:
$130 \mathrm{~km}$, average depth: $11 \mathrm{~m}$ ), and the upstream dam is Jirau (installed capacity: 3,750 MW, reservoir area: $362 \mathrm{~km}^{2}$, reservoir volume: $2747 \times 10^{6} \mathrm{~m}^{3}$, average depth: $11 \mathrm{~m}$ ). The Santo Antônio reservoir started filling in September 2011, reaching full pool in January 2012; filling of the Jirau reservoir started in October 2012 and reached full pool in May 2013. Because the Jirau dam is immediately upstream of the reservoir of Santo Antônio dam and it was filled shortly afterward, our observations speak to the combined effects of the two dams on the downstream river. Figure 2 illustrates how inflows are managed distinctly in run-of-river versus storage dams by comparing water inflows and outflows at the Santo Antonio (run-of-river) and the nearby Samuel dam (storage), located on a Madeira tributary (Jamari River; see Figure 1A); both dams are used to generate hydroelectricity.

\section{Hydrological Data}

Data on river stage and discharge between 2006 and 2018 were obtained from the Abunã, Porto Velho and Humaitá gaging stations (codes 15320002, 15400000, and 15630000, respectively), which are maintained by Brazil's National Water Agency ${ }^{1}$. The

${ }^{1}$ https://www.snirh.gov.br/hidroweb/

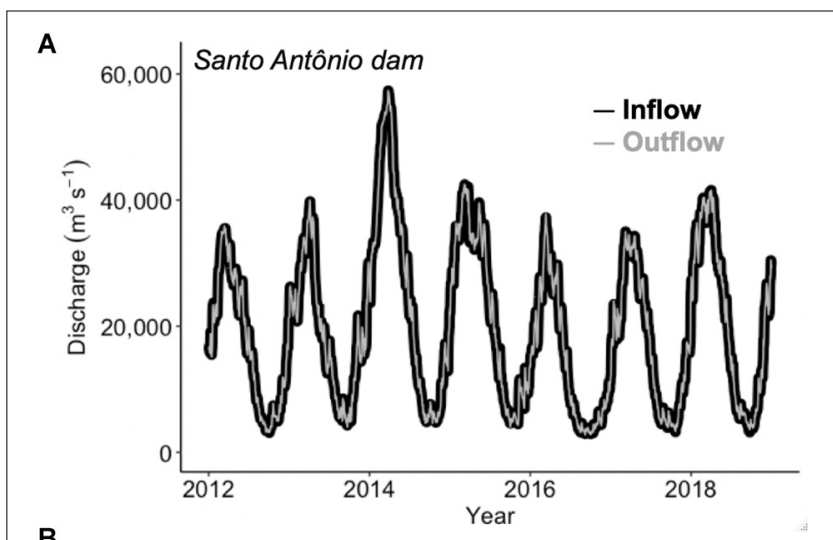

B

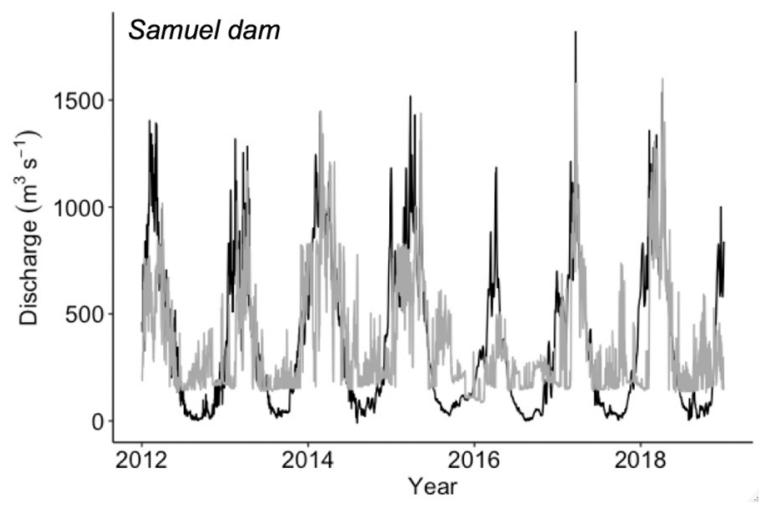

FIGURE 2 | Water inflow and outflow in run-of-river and storage dams. (A) Inflow and outflow discharges nearly matched each other at Santo Antônio, a run-of-river dam, between 2012 and 2018. (B) Inflow and outflow discharges were very different from each other at Samuel, a nearby storage dam. 
Abunã station, located about $5 \mathrm{~km}$ upstream of the Jirau reservoir (i.e., upstream of both dams; drainage area $921,000 \mathrm{~km}^{2}$ ), is used as a reference station. The Porto Velho station, located about $5 \mathrm{~km}$ downstream of the Santo Antônio dam (i.e., downstream of both dams; drainage area $976,000 \mathrm{~km}^{2}$ ), was used to assess direct hydrologic effects. The Humaitá station, located $\sim 250 \mathrm{~km}$ downstream from the Porto Velho station, was used to assess downstream attenuation of the observed hydrologic effects. We also analyzed hourly discharge and water level data for Abunã and Porto Velho between 2015 and 2018 (post-dam)-hourly data were not available for the pre-dam period. We estimated daily water residence times within the Jirau and Santo Antonio reservoirs by dividing daily river discharge (at Abunã for Jirau and at Porto Velho for Santo Antônio) by reservoir volume (Figure 1C); we call this the theoretical water residence time because it assumes complete mixing of river water within the entire reservoir.

The magnitude and duration of annual extreme water conditions were evaluated by calculating lowest and highest average daily flows over 3, 7, and 30-day periods for each year

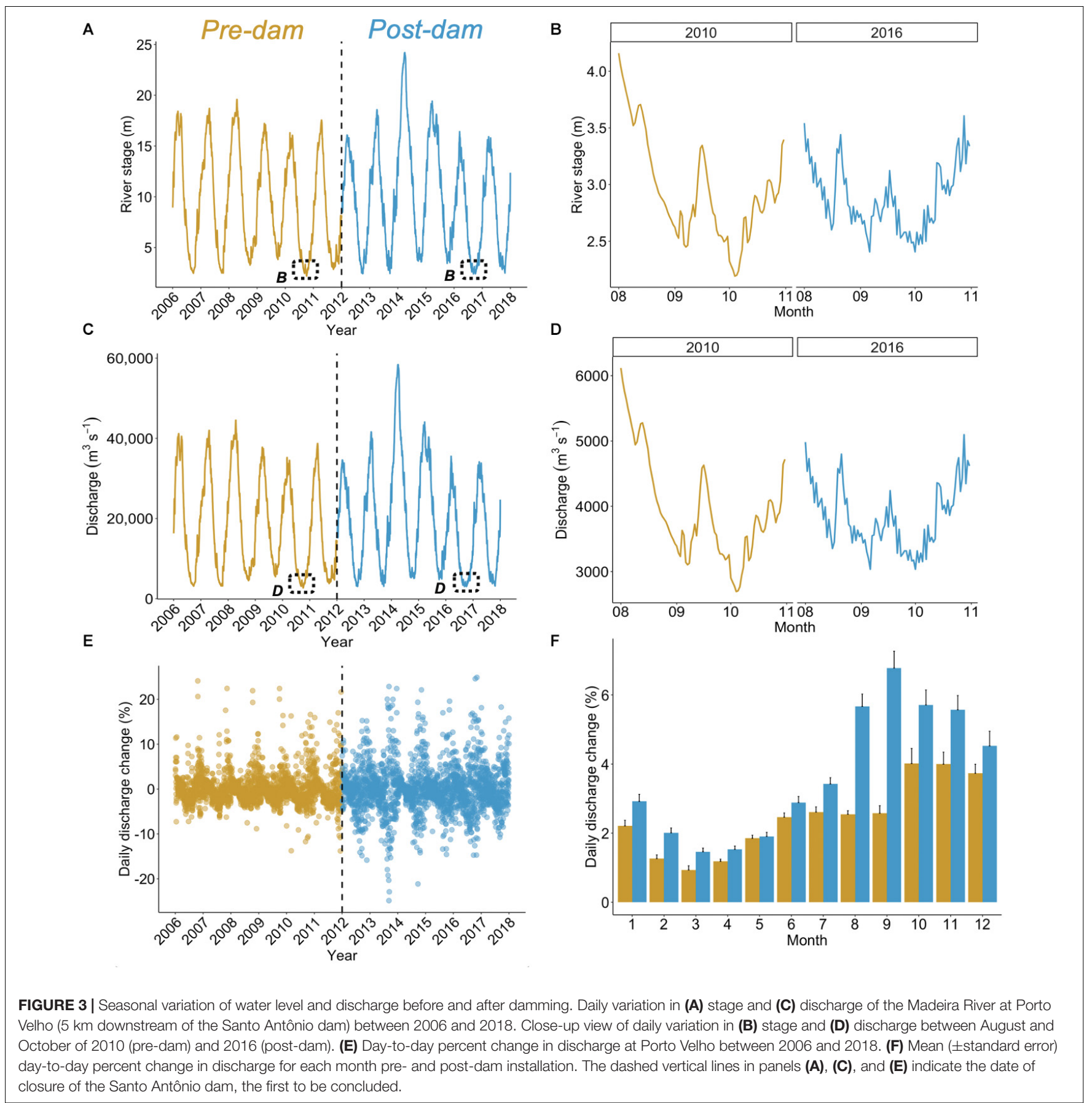


A
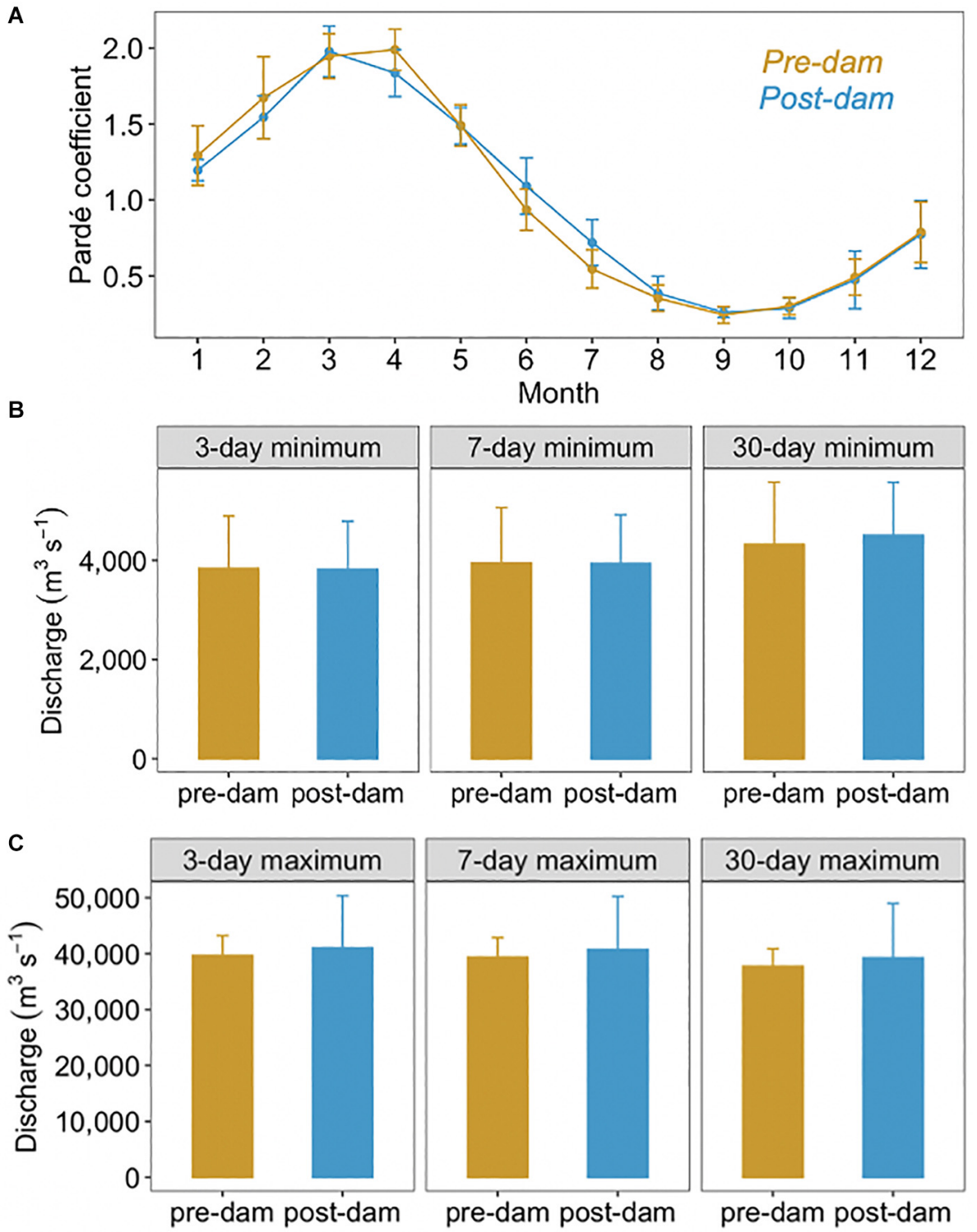

FIGURE 4 | Indicators of variability in seasonal flows based on daily discharge between 2006 and 2018. (A) Mean ( \pm standard deviation) monthly Pardé coefficients (i.e., mean monthly discharge divided by the mean annual discharge) of the Madeira River at Porto Velho (5 km downstream of the Santo Antônio dam). (B,C), Mean ( \pm standard deviation) annual 3, 7, and 30-day minimum and maximum discharges of the Madeira River at Porto Velho.

(The Nature Conservancy, 2009). We assessed the seasonality of the flow regime by calculating monthly Pardé coefficients, which are defined as mean monthly discharge divided by the mean annual discharge (Meile et al., 2011). Thus, comparison of pre- versus post-dam monthly Pardé coefficients allowed us to determine whether the dams have modified seasonal flood pulses. In addition to indicators of seasonal changes in the flow regime, we used several indicators of short-term hydrological alterations, namely the Richards-Baker (R-B) flashiness index, daily discharge fall and rise rate $\left(\mathrm{m}^{3} \mathrm{~s}^{-1}\right.$ day $\left.{ }^{-1}\right)$, number of reversals, hourly rate of water level change $\left(\mathrm{cm} \mathrm{h}^{-1}\right)$, and hourly discharge change rate $\left(\mathrm{HP} 1 ; \mathrm{m}^{3} \mathrm{~s}^{-1} \mathrm{~h}^{-1}\right)$, which is a dimensionless indicator of the magnitude of hydropeaking based on hourly discharge data. The R-B flashiness index is the sum of absolute daily change in discharge divided by the sum of average daily discharges (Baker et al., 2004). The rise rate is the daily change in discharge when it is increasing, whereas the fall rate is the daily change when discharge is decreasing. Reversals are changes from a rising period to a falling period or vice versa; here, a change in the sign of the difference between two consecutive days is considered as a reversal event. Daily discharge rise and fall rates and the number of reversals were calculated using Indicators of Hydrologic Alteration version 7.1, a freely available software (The Nature Conservancy, 2009). We used hourly discharge data to calculate HP1 for each day by dividing the difference between maximum and minimum discharge by 
A

B
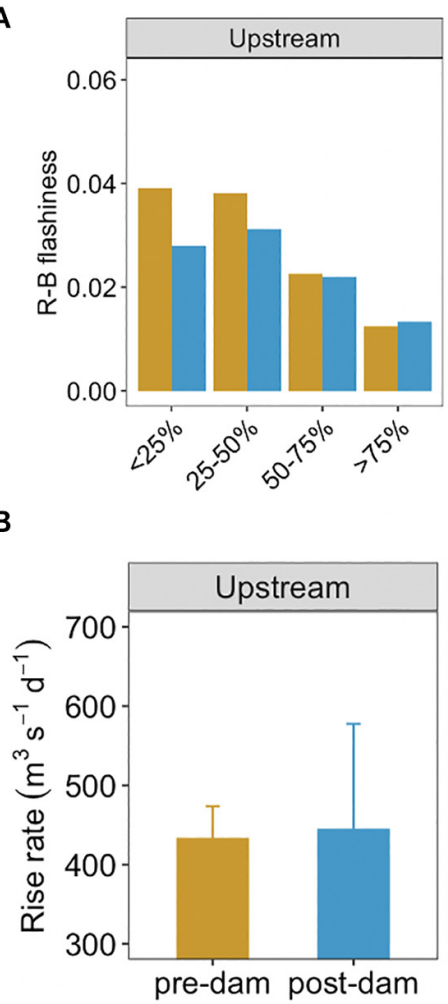

C

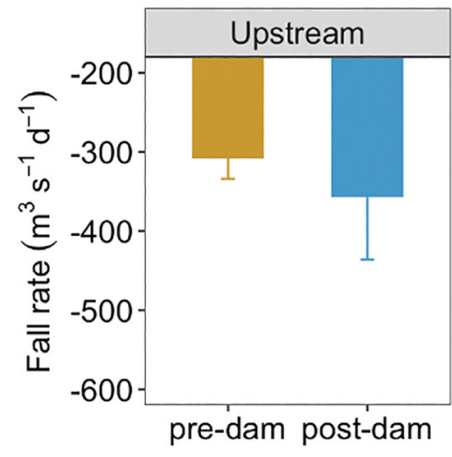

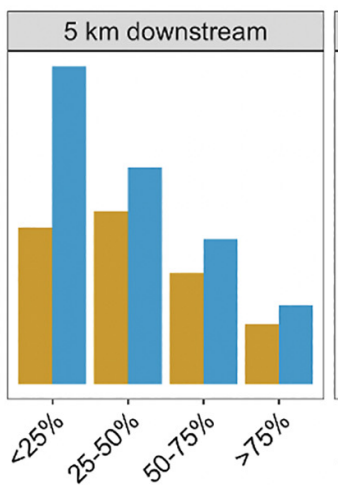

Discharge quartiles

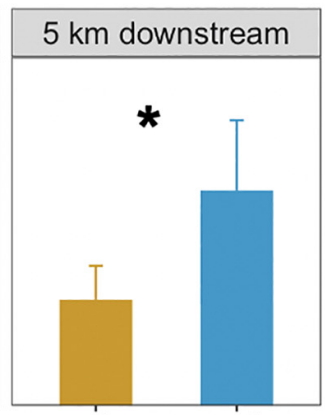

pre-dam post-dam
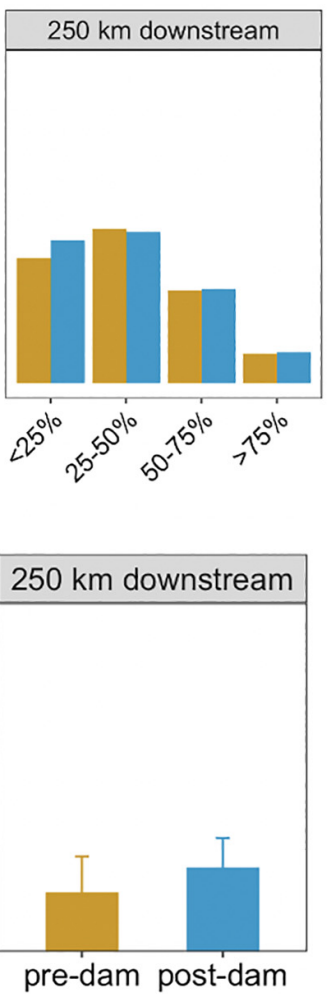
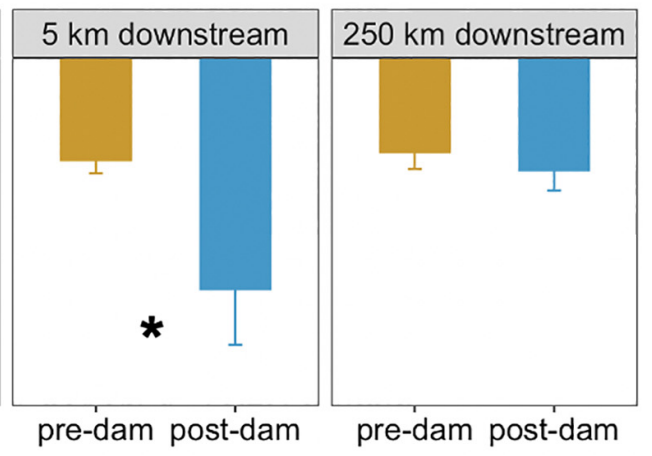

D
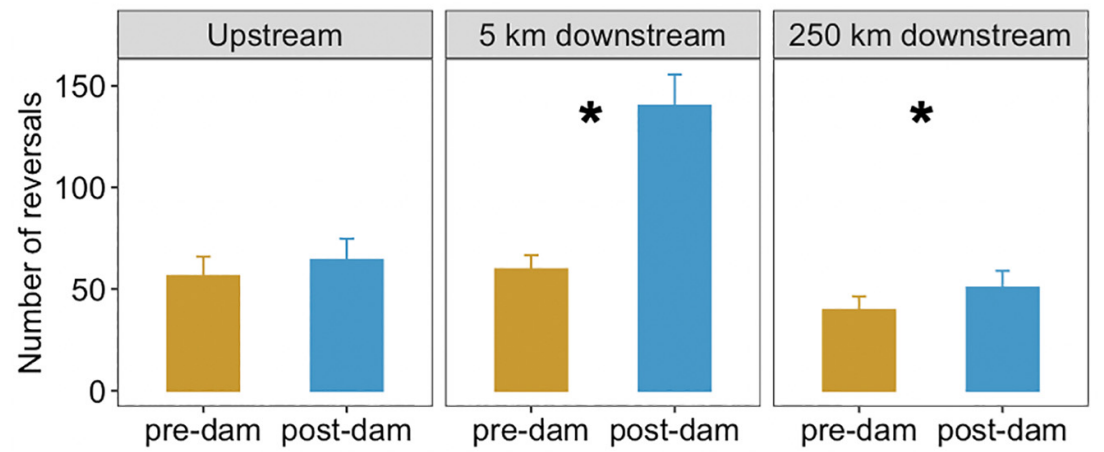

FIGURE 5 | Indicators of short-term variability in flow based on daily discharge between 2006 and 2018. (A) Pre- (2006-2011) and post-dam (2012-2017) Richards-Baker (R-B) flashiness index per discharge quartiles at Abunã (upstream of both dams), Porto Velho (5 km downstream) and Humaitá (250 km downstream). Pre- versus post-dam averages ( \pm standard deviation) of annual (B) discharge rise rates, (C) discharge fall rates, and (D) number of discharge reversals at Abunã, Porto Velho and Humaitá. Stars indicate significant pre- versus post-dam differences (two-tailed $t$-test, $p<0.05$ ). 
the daily mean (Carolli et al., 2015). The hydrologic parameters used here and their ecological implications are described in detail elsewhere (Richter et al., 1996; Baker et al., 2004; Meile et al., 2011; Carolli et al., 2015; Timpe and Kaplan, 2017). Our hydrological analyses compare six years of pre-dam flow data with six years of post-dam flow data, which has been shown to be a satisfactory length of record for flow analysis in low-elevation, high-discharge Amazonian rivers (Timpe and Kaplan, 2017).

\section{RESULTS}

\section{Effects on Downstream Seasonal Flood Pulses}

The markedly unimodal nature of the Madeira River's seasonal flood pulse was preserved downstream of the Jirau and Santo Antônio dams after their construction (Figures 3A,C), which becomes especially clear when comparing pre- and post-dam monthly Pardé coefficients (Figure 4C). The post-dam years spanned a wide range of discharge: 2014 had the largest annual average discharge on record, and 2016 had the second lowest annual average discharge on record, with records extending back to 1968. Still, the magnitude and duration of annual discharge maxima and minima were not significantly affected by dam closure (two-tailed $t$-test, $p>0.05$ ), as indicated by annual 3, 7, and 30-day minima and maxima below the dams (Figures 4A,B).

\section{Short-Term Effects on Downstream Flows}

Although we could not detect signs of disruption in seasonal flood pulses, the dams increased the short-term variability in discharge (Figures 5, 6). We found significant post-dam increases in the R-B flashiness index (Figure 5A), daily discharge rise and fall rates (Figures 5B,C), and number of reversals at Porto Velho (Figure 5D). The mean absolute day-to-day change in discharge nearly doubled after dam closure, increasing from 2.3 to $3.9 \%$ (Figures 3E,F). The pre- vs. post-dam difference in discharge flashiness increased as discharge decreased (Figures 3C,E, 5A), coinciding with periods of higher water residence time within the reservoir (Figure 1C). The day-to-day hydrological alterations observed at Porto Velho ( $\sim 5 \mathrm{~km}$ downstream of the Santo Antônio dam) are considerably attenuated a few hundred $\mathrm{km}$ downstream, as suggested by a lack of significant difference between pre- and post-dam discharge rise and fall rates at the next gaging station (Humaitá, $\sim 250 \mathrm{~km}$ downstream of the Santo Antônio dam) (Figures 5A-C). The difference in the number of reversals $250 \mathrm{~km}$ downstream of the dam was still significant, but much less pronounced than at Porto Velho (Figure 5D). In addition, the low-flow flashiness index at Humaitá was only 13\% higher in the post-dam period, as compared to $94 \%$ higher at Porto Velho (Figure 5A).

Dam operations have also altered downstream flashiness on a sub-daily basis (Figure 6). Hourly discharge data available for Porto Velho ( $5 \mathrm{~km}$ downstream of the dams) and Abunã (reference station, upstream of both dams) between 2015 and 2018 (post-dam) indicates that the dams have doubled the magnitude of hydropeaks (Figure 6A). In addition, the hourly rate of change in discharge and water level is more variable in response to dam operations, as indicated by interquartile ranges that are three times larger downstream compared to upstream of the dams (Figures $\mathbf{6 B}, \mathbf{C}$ ). The hourly rate of discharge and water level changes downstream of the dams has a clear diel pattern, being positively correlated with the median hourly electricity demand from Brazil's North subsystem for the same time period $(r=0.58, p<0.05)$ (Figure 7).

\section{DISCUSSION}

Our results suggest that the two large run-of-river dams recently built on the Madeira River have not altered downstream seasonal flood pulses, which was anticipated in pre-dam environmental impact studies. However, the operation of these dams significantly increased short-term (daily and sub-daily) flow variability. The observed increase in short-term flashiness downstream of the dams is in part associated with the satisfaction of peak electricity demand, as indicated by a positive correlation
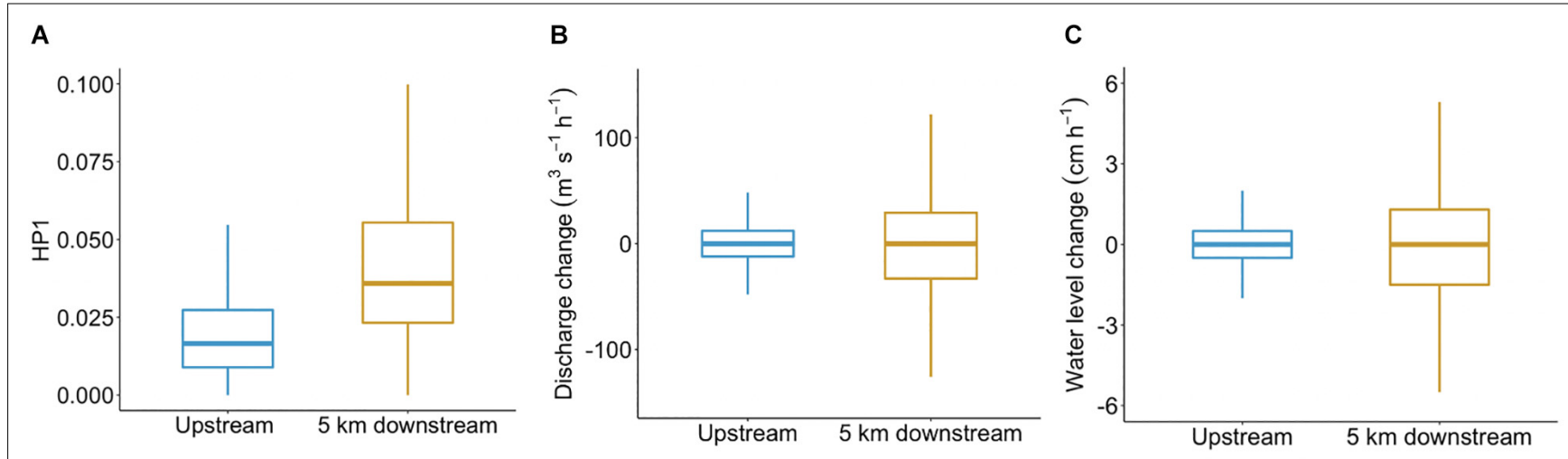

FIGURE 6 | Sub-daily rate of change of flow downstream of the dams. (A) Dimensionless indicator of the magnitude of hydropeaking (HP1) on the Madeira River based on hourly discharge data at Abunã (upstream of both dams) and Porto Velho (5 km downstream of Santo Antônio dam). Hourly rate of change in (B) discharge and (C) water level upstream and downstream of the dams. 


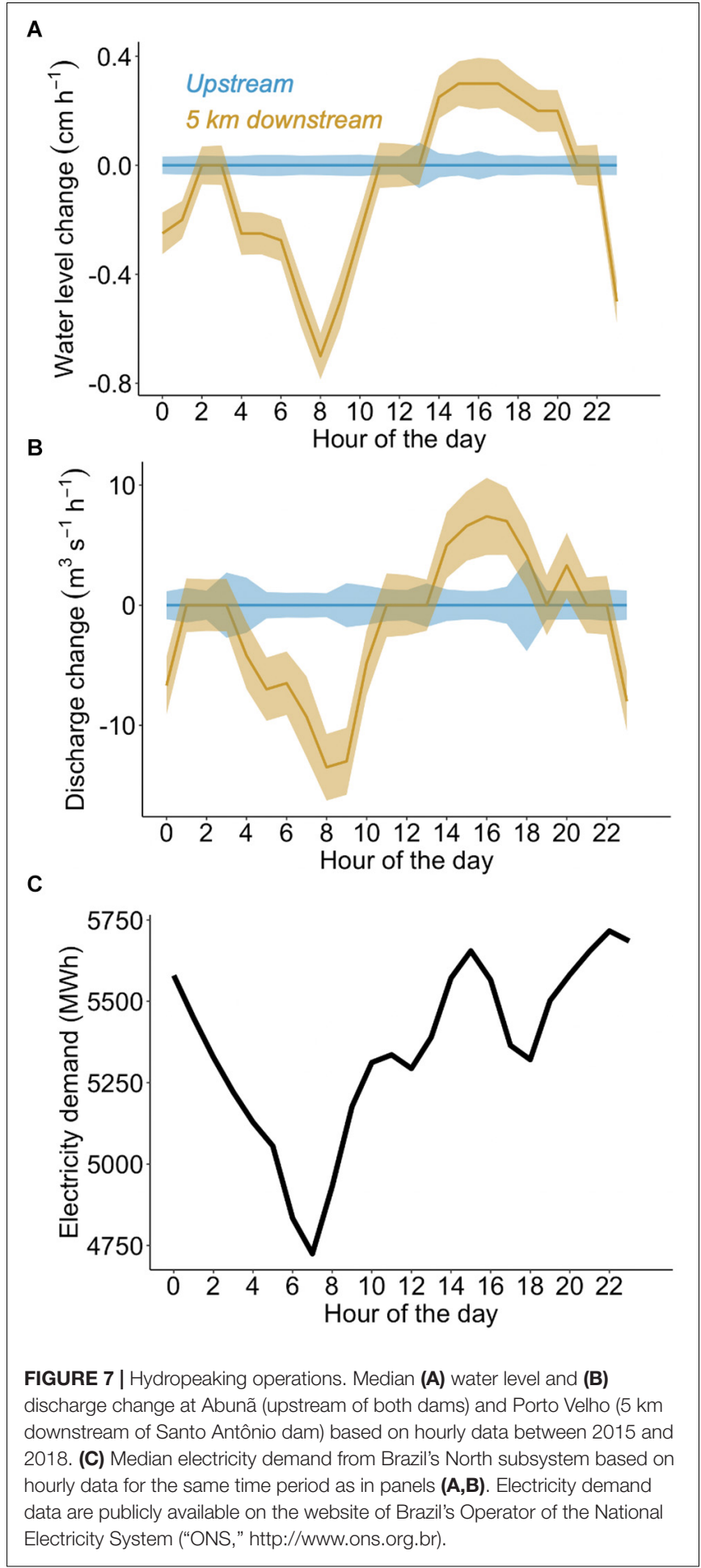

between median hourly discharge change rates and median hourly electricity demand $(r=0.58, p<0.05$; Figure 7$)$. There is downstream attenuation of the short-term fluctuations, likely explained by mitigating effects of water inflow from tributaries such as the Ji-Paraná and Jamari rivers, as well as channel and floodplain effects (De Paiva et al., 2013; Lininger and Latrubesse, 2016).

Studies on the environmental consequences of hydropeaking in the Amazon Basin are lacking. But effects of hydropeaking have been studied in many other smaller river systems (Zimmerman et al., 2010; Bevelhimer et al., 2015; Kennedy et al., 2016; Bejarano et al., 2018) and include destabilization of sediment accumulations along river bars, disruption of plant and animal life cycles in nearshore zones, and stranding of fishes. Human use of riparian zones and floodplains for growing crops can also be negatively affected in regions with flood-recession agriculture (Richter et al., 2010). Studies in Northern Hemisphere rivers show that hydropeaking causes substantial stranding and entrapment of early life stages of various salmonid fish species, with downramping rates as low as $2.4 \mathrm{~cm} \mathrm{~h}^{-1}$ potentially leading to significant stranding. The median sub-daily rate of water level change $\left(1.5 \mathrm{~cm} \mathrm{~h}^{-1}\right)$ downstream of the Madeira dams is three times higher than upstream, with rates staying above $2.5 \mathrm{~cm} \mathrm{~h}^{-1}$ during $30 \%$ of the time (Figure $6 \mathrm{C}$ ).

Our findings do not allow us to directly link hydropeaking to social and ecological impacts downstream of the dams. But results from a recent ethnobiological study suggest that it is possible that the increased hydropeaking reported here is leading to important socio-ecological consequences downstream of the Madeira dams. Local fishers perceive changes to natural flow regimes as the most negative impact of the Madeira dams (Santos et al., 2020). More specifically, fishers contend that sudden variations in river levels (locally known as "repiquetes") are the most relevant hydrologic impact of the Madeira dams. Some fishers argue that the increased irregularity and unpredictability of the flow regime caused by hydropeaking negatively affect fish catches; according to them, catches increase when river levels begin to fall, and then decrease when the dam releases water (Santos et al., 2020).

Indeed, recent studies report considerable declines in fishery yields downstream of the Madeira dams (Santos et al., 2018; Lima et al., 2020). One of these studies attributed the declines to a combination of blockage of migratory routes by the Madeira dams as well as dam operations that increased downstream water levels (making fishing more difficult) and caused greater water level variability (which could affect fish behavior) (Santos et al., 2018). Our results suggest that the higher post-dam discharges are unlikely to be dam-related, particularly considering that the two dams are not capable of increasing water levels and discharge over annual time scales because their reservoirs do not vary much in volume. Although the average post-dam discharge $\left(19,451 \mathrm{~m}^{3} \mathrm{~s}^{-1}\right)$ was about $6 \%$ higher than the average predam discharge $\left(18,396 \mathrm{~m}^{3} \mathrm{~s}^{-1}\right)$, when we exclude the year 2014, characterized by the largest flood on record, the average post-dam discharge $\left(18,082 \mathrm{~m}^{3} \mathrm{~s}^{-1}\right)$ becomes very similar to the average pre-dam discharge. Still, the reported decline in downstream fisheries is consistent with the increased shortterm variability in downstream flows that we report, especially considering that the rate of change in discharge has been demonstrated to be an important regulator of fishery yields in the Madeira River (Lima et al., 2017). In fact, local fishers claim that the abrupt daily changes in downstream water levels caused by dam operations disrupt cues that trigger the 
reproductive migration of fish from nutrient-poor, clear-water tributaries to the nutrient-rich mainstem of the Madeira River (C. Doria, personal observation). Whether hydropeaking effectively disrupts fish migrations remains unknown and merits further investigation. Also, species-specific studies are needed to identify whether observed hydropeaking rates can affect early life stages of fish species inhabiting the Madeira River downstream of the dams.

In summary, our study shows that hydropeaking occurs downstream of the dam. Understanding if and how this hydrological effect translates into social and ecological impacts will be critical to assess the need for mitigation and control strategies. Given the existence of a downstream gage with high-frequency flow data, early warning systems could be developed by dam operators in conjunction with local authorities to alert downstream human populations about abrupt water level changes. Operational protocols that reduce hydropeaking could mitigate its undesirable hydrological, geomorphological, ecological, and social effects on downstream reaches (Greimel et al., 2018; Moreira et al., 2019).

\section{PROSPECTS}

Brazilian energy planners and policy makers often advocate the prioritization of storage dams over run-of-river projects for energy security purposes (Abbud and Tancredi, 2010; Cerqueira, 2015), especially considering that the limited energy storage of Amazonian run-of-river dams is likely to get worse in light of climate variability (Stickler et al., 2013; Hunt et al., 2014; Lima et al., 2014). The push for storage dams in the Amazon River system could be facilitated by the current trend toward relaxation of environmental regulations that would make project selection less restrictive in Brazil (Almeida et al., 2016; Fearnside, 2016). Run-of-river dams are likely preferable designs in terms of downstream impacts because storage dams not only lead to hydropeaking, but also cause large-scale changes in seasonal flood pulses (Timpe and Kaplan, 2017). However, the electricity generation by run-of-river facilities is more susceptible to droughts, which could become more common with future increases in climate variability and deforestation in the Amazon basin (Marengo et al., 2009; Stickler et al., 2013; Arias et al., 2020). The effects of ongoing environmental changes on future Amazon hydroelectricity generation and the associated environmental impacts must be critically understood before new dams are constructed.

In conclusion, despite the potential for dams to alter downstream hydrology throughout the world (Lehner et al., 2011; Grill et al., 2019), a suite of other impacts

\section{REFERENCES}

Abbud, O. A., and Tancredi, M. (2010). Transformações Recentes da Matriz Brasileira de Geração de Energia Elétrica - Causas e Impactos Principais: Boletim Legislativo no 69, de 2010. Brasília: Núcleo de Estudos e Pesquisas/CONLEG/Senado. must be factored into decisions about the optimal locations and design of new facilities (World Commission on Dams, 2000). Dam proposals must be evaluated in the context of their impacts on the overall river system, extending across national boundaries and including deltas and coastal waters into which rivers flow (Latrubesse et al., 2017). Uncoordinated construction of dams throughout the world has resulted in environmental impacts that could have been minimized through strategic basin-wide dam planning (Schmitt et al., 2018; Almeida et al., 2019b). New frameworks for watershed-wide, multiobjective optimization of dam planning have recently been proposed for major river basins of the world (Ziv et al., 2012; Schmitt et al., 2019), including the Amazon (Almeida et al., 2019b). It is imperative to consider potential hydrological effects along with other social and environmental impacts related to future Amazon dams.

\section{DATA AVAILABILITY STATEMENT}

The raw data supporting the conclusions of this article will be made available by the authors, without undue reservation, to any qualified researcher.

\section{AUTHOR CONTRIBUTIONS}

RA, SH, ER, and FR conceived this study. RA, SH, and AyF analyzed the data. RA wrote the manuscript in close collaboration with $\mathrm{SH}$ and with substantive revision by all authors. All authors worked on the interpretation of the data.

\section{FUNDING}

Funding for RA was provided by a Cornell Atkinson Center for Sustainability postdoctoral fellowship, a Cary Institute Award for Graduate Student Research (Bentley Holden scholarship), and a scholarship from Brazil's Ciência sem Fronteiras program (CNPq 201848/2015-5).

\section{ACKNOWLEDGMENTS}

We thank Edgardo Latrubesse and Thomas Dunne for providing valuable comments on earlier versions of the manuscript. We are also grateful to André Amado, Jean Ometto, Luiz Martinelli, Vera Huszar, the Amazon Dams Computational Sustainability working group, and the technical staff of the environmental consulting firm Ecology Brasil.

Almeida, R. M., Hamilton, S. K., Rosi, E. J., Arantes, J. D., Barros, N., Boemer, G., et al. (2019a). Limnological effects of a large Amazonian run-of-river dam on the main river and drowned tributary valleys. Sci. Rep. 9:16846.

Almeida, R. M., Shi, Q., Gomes-Selman, J. M., Wu, X., Xue, Y., Angarita, H., et al. (2019b). Reducing greenhouse gas emissions of Amazon hydropower with strategic dam planning. Nat. Commun. 10:4281. 
Almeida, R. M., Lovejoy, T. E., and Roland, F. (2016). Brazil's Amazon conservation in peril. Science 353, 228-229.

Almeida, R. M., Tranvik, L., Huszar, V. L. M., Sobek, S., Mendonca, R., Barros, N., et al. (2015). Phosphorus transport by the largest Amazon tributary (Madeira River. Brazil) and its sensitivity to precipitation and damming. Inland Waters 5 , 275-282. doi: 10.5268/iw-5.3.815

Anderson, D., Moggridge, H., Warren, P., and Shucksmith, J. (2015). The impacts of 'run-of-river' hydropower on the physical and ecological condition of rivers. Water Environ. J. 29, 268-276. doi: 10.1111/wej.12101

Anderson, E. P., Jenkins, C. N., Heilpern, S., Maldonado-Ocampo, J. A., CarvajalVallejos, F. M., Encalada, A. C., et al. (2018). Fragmentation of Andes-toAmazon connectivity by hydropower dams. Sci. Adv. 4:eaao1642. doi: 10.1126/ sciadv.aao 1642

Arias, M. E., Farinosi, F., Lee, E., Livino, A., Briscoe, J., and Moorcroft, P. R. (2020). Impacts of climate change and deforestation on hydropower planning in the Brazilian Amazon. Nat. Sustain. 3, 430-436. doi: 10.1038/s41893-020-0492-y

Ashraf, F. B., Haghighi, A. T., Riml, J., Alfredsen, K., Koskela, J. J., Kløve, B., et al. (2018). Changes in short term river flow regulation and hydropeaking in Nordic rivers. Sci. Rep. 8:17232.

Ayes, R. I., Armijos, C. E., Espinoza-Villar, R., Espinoza, J. C., Molina-Carpio, J., Ayala, J. M., et al. (2019). Decline of fine suspended sediments in the madeira river basin (2003-2017). Water 11:514. doi: 10.3390/w11030514

Baker, D. B., Richards, R. P., Loftus, T. T., and Kramer, J. W. (2004). A new flashiness index: characteristics and applications to Midwestern rivers and streams. JAWRA 40, 503-522. doi: 10.1111/j.1752-1688.2004.tb01046.x

Bejarano, M. D., Jansson, R., and Nilsson, C. (2018). The effects of hydropeaking on riverine plants: a review. Biol. Rev. 93, 658-673. doi: 10.1111/brv.12362

Bevelhimer, M. S., Mcmanamay, R. A., and O'connor, B. (2015). Characterizing sub-daily flow regimes: implications of hydrologic resolution on ecohydrology studies. River Res. Appl. 31, 867-879. doi: 10.1002/rra.2781

Carolli, M., Vanzo, D., Siviglia, A., Zolezzi, G., Bruno, M. C., and Alfredsen, K. J. A. S. (2015). A simple procedure for the assessment of hydropeaking flow alterations applied to several European streams. Aqu. Sci. 77, 639-653. doi: 10.1007/s00027-015-0408-5

Cerqueira, G. A. (2015). A Crise Hídrica e suas Consequências: Boletim Legislativo no 27, de 2015. Brasília: Núcleo de Estudos e Pesquisas/CONLEG/Senado.

Cochrane, S. M. V., Matricardi, E. A. T., Numata, I., and Lefebvre, P. A. (2017). Landsat-based analysis of mega dam flooding impacts in the Amazon compared to associated environmental impact assessments: upper Madeira River example 2006-2015. Remote Sens. Appl. 7, 1-8. doi: 10.1016/j.rsase.2017.04.005

Csiki, S. J. C., and Rhoads, B. L. (2014). Influence of four run-of-river dams on channel morphology and sediment characteristics in Illinois, USA. Geomorphology 206, 215-229. doi: 10.1016/j.geomorph.2013.10.009

De Faria, F. A. M., Jaramillo, P., Sawakuchi, H. O., Richey, J. E., and Barros, N. (2015). Estimating greenhouse gas emissions from future Amazonian hydroelectric reservoirs. Environ. Res. Lett. 10:011002. doi: 10.1088/1748-9326/ $11 / 1 / 011002$

De Paiva, R. C. D., Buarque, D. C., Collischonn, W., Bonnet, M.-P., Frappart, F., Calmant, S., et al. (2013). Large-scale hydrologic and hydrodynamic modeling of the Amazon River basin. Water Resour. Res. 49, 1226-1243. doi: 10.1002/ wrcr.20067

Fearnside, P. M. (2016). Brazilian politics threaten environmental policies. Science 353:746. doi: 10.1126/science.aag0254

Forsberg, B. R., Melack, J. M., Dunne, T., Barthem, R. B., Goulding, M., Paiva, R. C. D., et al. (2017). The potential impact of new Andean dams on Amazon fluvial ecosystems. PLoS One 12:e0182254. doi: 10.1371/journal.pone.0182254

Greimel, F., Schülting, L., Graf, W., Bondar-Kunze, E., Auer, S., Zeiringer, B., et al. (2018). "Hydropeaking impacts and mitigation," in Riverine Ecosystem Management: Science for Governing Towards a Sustainable Future, eds S. Schmutz and J. Sendzimir (Cham: Springer International Publishing), 91-110. doi: 10.1007/978-3-319-73250-3_5

Grill, G., Lehner, B., Thieme, M., Geenen, B., Tickner, D., Antonelli, F., et al. (2019). Mapping the world's free-flowing rivers. Nature 569, 215-221.

Hunt, J. D., Freitas, M. A. V., and Pereira, A. O. Jr. (2014). Enhanced-PumpedStorage: combining pumped-storage in a yearly storage cycle with dams in cascade in Brazil. Energy 78, 513-523. doi: 10.1016/j.energy.2014.10.038

Junk, W. J., Bayley, P. B., and Sparks, R. E. (1989). The flood pulse concept in river-floodplain system. Can. Spec. Publ. Fish Aquat. Sci. 106, 110-127.
Kennedy, T. A., Muehlbauer, J. D., Yackulic, C. B., Lytle, D. A., Miller, S. W., Dibble, K. L., et al. (2016). Flow management for hydropower extirpates aquatic insects, undermining river food webs. BioScience 66, 561-575. doi: 10.1093/ biosci/biw059

Latrubesse, E. M., Arima, E. Y., Dunne, T., Park, E., Baker, V. R., D’horta, F. M., et al. (2017). Damming the rivers of the Amazon basin. Nature 546, 363-369. doi: $10.1038 /$ nature 22333

Lehner, B., Liermann, C. R., Revenga, C., Vorosmarty, C., Fekete, B., Crouzet, P., et al. (2011). High-resolution mapping of the world's reservoirs and dams for sustainable river-flow management. Front. Ecol. Environ. 9, 494-502. doi: $10.1890 / 100125$

Lima, J. W. M., Collischonn, W., and Marengo, J. A. (2014). Efeitos das Mudanças Climáticas na Geração de Energia Elétrica, 1 Edn, Vol. 3. São Paulo, CA: Hunter, 282.

Lima, M. A., Rosa, C. A., Alexandre, N. M., Angelini, R., Da Costa, R. et al. (2020). Declining fisheries and increasing prices: the economic cost of tropical rivers impoundment. Fish. Res. 221:105399. doi: 10.1016/j.fishres.2019.105399

Lima, M. A. L. (2017). História do Ecossistema e dos Recursos Pesqueiros Frente a Implementação de Hidrelétricas na Bacia do rio Madeira. Ph.D. thesis, Federal University of Rondônia, Porto Velho.

Lima, M. A. L., Kaplan, D. A., and Doria, C. R. C. (2017). Hydrological controls of fisheries production in a major Amazonian tributary. Ecohydrology 10:e1899. doi: $10.1002 /$ eco.1899

Lininger, K. B., and Latrubesse, E. M. (2016). Flooding hydrology and peak discharge attenuation along the middle Araguaia River in central Brazil. Catena 143, 90-101. doi: 10.1016/j.catena.2016.03.043

Marengo, J. A., Jones, R., Alves, L. M., and Valverde, M. C. (2009). Future change of temperature and precipitation extremes in South America as derived from the PRECIS regional climate modeling system. Int. J. Climatol. 29, 2241-2255. doi: $10.1002 /$ joc. 1863

McClain, M. E., and Naiman, R. J. (2008). Andean influences on the biogeochemistry and ecology of the Amazon River. BioScience 58, 325-338. doi: $10.1641 / \mathrm{b} 580408$

Meile, T., Boillat, J. L., and Schleiss, A. J. (2011). Hydropeaking indicators for characterization of the Upper-Rhone River in Switzerland. Aquat. Sci. 73, 171-182. doi: 10.1007/s00027-010-0154-7

Moreira, M., Hayes, D. S., Boavida, I., Schletterer, M., Schmutz, S., and Pinheiro, A. (2019). Ecologically-based criteria for hydropeaking mitigation: a review. Sci. Total Environ. 657, 1508-1522. doi: 10.1016/j.scitotenv.2018.12.107

Nilsson, C., and Berggren, K. (2000). Alterations of Riparian Ecosystems Caused by River RegulationDam operations have caused global-scale ecological changes in riparian ecosystems. How to protect river environments and human needs of rivers remains one of the most important questions of our time. BioScience 50, 783-792.

Poff, N. L., Allan, J. D., Bain, M. B., Karr, J. R., Prestegaard, K. L., Richter, B. D., et al. (1997). The natural flow regime. BioScience 47, 769-784.

Richter, B., Baumgartner, J. V., Powell, J., and Braun, D. P. (1996). A method for assessing hydrologic alteration within ecosystems. Conserv. Biol. 10, 1163-1174. doi: 10.1046/j.1523-1739.1996.10041163.x

Richter, B. D., Postel, S., Revenga, C., Scudder, T., and Lehner, B. (2010). Lost in development's shadow: the downstream human consequences of dams. Water Alterna. 3, 14-42.

Santos, R. E., Pinto-Coelho, R. M., Drumond, M. A., Fonseca, R., and Zanchi, F. B. J. A. (2020). Damming amazon rivers: environmental impacts of hydroelectric dams on Brazil's Madeira River according to local fishers' perception. Ambio 20, 1-7. doi: 10.1007/s13280-020-01316-w

Santos, R. E., Pinto-Coelho, R. M., Fonseca, R., Simões, N. R., and Zanchi, F. B. (2018). The decline of fisheries on the Madeira River, Brazil: the high cost of the hydroelectric dams in the Amazon Basin. Fish. Manag. Ecol. 25, 380-391. doi: 10.1111/fme.12305

Schmitt, R. J. P., Bizzi, S., Castelletti, A., and Kondolf, G. M. (2018). Improved trade-offs of hydropower and sand connectivity by strategic dam planning in the Mekong. Nat. Sustain. 1, 96-104. doi: 10.1038/s41893-018-0022-3

Schmitt, R. J. P., Bizzi, S., Castelletti, A., Opperman, J. J., and Kondolf, G. M. (2019). Planning dam portfolios for low sediment trapping shows limits for sustainable hydropower in the Mekong. Sci. Adv. 5:eaaw2175. doi: 10.1126/sciadv.aaw2175

Stickler, C. M., Coe, M. T., Costa, M. H., Nepstad, D. C., Mcgrath, D. G., Dias, L. C. P., et al. (2013). Dependence of hydropower energy generation on forests 
in the Amazon Basin at local and regional scales. Proc. Natl. Acad. Sci. U.S.A. 110, 9601-9606. doi: 10.1073/pnas.1215331110

The Nature Conservancy (2009). Indicators of Hydrologic Alteration 7.1. Arlington, VA: The Nature Conservancy.

Timpe, K., and Kaplan, D. (2017). The changing hydrology of a dammed Amazon. Sci. Adv. 3:e1700611. doi: 10.1126/sciadv.1700611

Winemiller, K. O., Mcintyre, P. B., Castello, L., Fluet-Chouinard, E., Giarrizzo, T., Nam, S., et al. (2016). Balancing hydropower and biodiversity in the Amazon, Congo, and Mekong. Science 351, 128-129.

World Commission on Dams (2000). Dams and Development: A New Framework for Decision-Making. London: Earthscan Publications Ltd.

Zimmerman, J. K. H., Letcher, B. H., Nislow, K. H., Lutz, K. A., and Magilligan, F. J. (2010). Determining the effects of dams on subdaily variation in river flows at a whole-basin scale. River Res. Appl. 26, 1246-1260. doi: 10.1002/rra. 1324
Ziv, G., Baran, E., Nam, S., Rodríguez-Iturbe, I., and Levin, S. A. (2012). Tradingoff fish biodiversity, food security, and hydropower in the Mekong River Basin. Proc. Natl. Acad. Sci. U.S.A. 109, 5609-5614. doi: 10.1073/pnas.1201423109

Conflict of Interest: The authors declare that the research was conducted in the absence of any commercial or financial relationships that could be construed as a potential conflict of interest.

Copyright (c) 2020 Almeida, Hamilton, Rosi, Barros, Doria, Flecker, Fleischmann, Reisinger and Roland. This is an open-access article distributed under the terms of the Creative Commons Attribution License (CC BY). The use, distribution or reproduction in other forums is permitted, provided the original author(s) and the copyright owner(s) are credited and that the original publication in this journal is cited, in accordance with accepted academic practice. No use, distribution or reproduction is permitted which does not comply with these terms. 